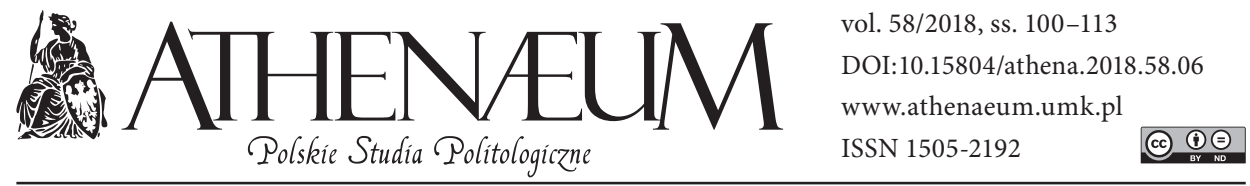

\title{
DETERMINANTY CHWIEJNOŚCI WYBORCZEJ NA POZIOMIE LOKALNYM
}

\author{
DETERMINANTS OF ELECTORAL VOLATILITY \\ AT THE LOCAL LEVEL
}

Agnieszka Turska-Kawa*

\begin{abstract}
ABSTRAKT
Celem artykułu jest weryfikacja czynników decydujących o specyfice chwiejności wyborczej na poziomie samorządowym. Polityka lokalna kieruje się innymi prawami, odmiennymi kanałami dociera do wyborców, inaczej ich aktywizuje. W większej mierze dostępne są jej mechanizmy bliższe obywatelom, dotykające bezpośrednio ich codziennego życia. Artykuł podejmuje analizę uwarunkowań, które odgrywają istotną rolę w generowaniu modeli zachowań wyborczych na poziomie lokalnym. Przedstawiona refleksja obejmuje czynniki wynikające $\mathrm{z}$ drugorzędności wyborów samorządowych, szczególne motywacje wyborcze obywateli, tematy kampanijne oraz specyfikę tworzenia komitetów i generowania kandydatów niezwiązanych $\mathrm{z}$ partiami politycznymi. Refleksję poprzedza przedstawienie głównych zagadnień teoretycznych związanych z chwiejnością wyborczą.
\end{abstract}

Słowa kluczowe: chwiejność wyborcza, wybory samorządowe, zachowania wyborcze
The aim of this article is to verify the determinants of electoral volatility in local elections. Local politics is different from national politics, it has its own rules, it uses different channels to reach voters. Local politicians can use mechanism based on direct contact with voters more freely. This article analyzes determinants that play an important role in shaping voter's behavior on the local level. Conclusions drawn present determinants that stem from the second-order character of local elections, specific voter's motivations, campaigning themes, as well as peculiarity of independent candidate creation and the construction of committees. All this is preceded with a general reflection on theoretical tenets of electoral volatility.

Keywords: electoral volatility, local elections, voter's behavior

* Uniwersytet Śląski w Katowicach, Instytut Nauk Politycznych i Dziennikarstwa. 


\section{WPROWADZENIE}

Chwiejność wyborcza jest jednym z ważnych wskaźników strukturalnych zmian zachowań wyborczych (Mair, 2005). Koniec XX wieku to okres, w którym coraz częściej pojawiały się analizy wskazujące na osłabianie więzi między wyborcami a partiami politycznymi, zaś diagnozowane zmiany wartości politycznych czy zmieniające się podziały socjopolityczne wpływały na trudności w przewidywaniu zachowań wyborczych obywateli. Badacze wskazywali na coraz słabszą identyfikację partyjną we współczesnych demokracjach (Dalton, Wattenberg, 1993, s. 193-218). Wśród uwarunkowań tego stanu wskazywano m.in. na załamanie się tradycyjnych podziałów socjopolitycznych (Russell, Beck, Flanagan, 1984; Franklin, Mackie, Valen, 1992), mobilizację poznawczą obywateli (Dalton, 1984; Inglehart, 1970; Nie, Verba, Petrocik, 1979). Wynika ona m.in. z coraz większej powszechności edukacji, zmniejszenia kosztów pozyskiwania informacji politycznej, zwiększenia zasobów obywateli w pozyskiwaniu nowych informacji i ich weryfikacji czy zmiany na poziomie funkcjonowania partii politycznych, które w coraz mniejszym stopniu spełniają swoje tradycyjne funkcje, a przyjmują nowe, bardziej doraźne, ukierunkowane na krótkoterminowe cele, m.in. w płaszczyźnie komunikacji z wyborcami czy ekspresji celów programowych.

Powyższe obserwacje tworzą coraz szerszą przestrzeń dla mniej stabilnego elektoratu. Z jednej strony tego, który przyciągany jest sporadycznie, nie wykazując wewnętrznej potrzeby współudziału w podejmowaniu ważnych dla państwa i społeczeństwa decyzji. Elektorat ten można nazwać niestabilnym, uczestniczącym incydentalnie w elekcjach. $Z$ drugiej strony przestrzeń ta tworzy miejsce dla wyborców aktywnie uczestniczących w procesie wyborczym, jednak niezwiązanych lojalnością z żadnym podmiotem. B.C. Hayes i I. McAllister (1996, s. 127-139) nazywają ich wyborcami przepływającymi (floating voters), wskazując, że strategie oddziaływania wyborczego w zdecydowanej mierze powinny się odwoływać do tego segmentu, bowiem jest on najbardziej wrażliwy na wpływ kampanii. Tak zdefiniowanemu typowi wyborców badacze przypisują różne cechy: mniejszy fanatyzm polityczny (Converse, 1962, s. 578-599; Zaller, 2003, s. 109-130), większą podatność na oddziaływanie mediów (Zukin 1977, s. 244-254), posiadanie mniejszego zakresu informacji politycznej (Haller, 2003, s. 109-130). Wyniki badań S. Chaffee oraz S.Y. Choe (1980, s. 53-69) wskazują, że wyborcy niezdecydowani słabiej różnicują wizerunki kandydatów w elekcjach, wykazują słabszą identyfikację z określoną partią oraz są mniej wykształceni. Wyjaśnianie zachowań wyborczych obywateli na podstawie długoterminowych 
czynników, takich jak np. miejsce zajmowane w strukturze społecznej, stało się zatem niewystarczające, a dotarcie do wielopłaszczyznowych uwarunkowań chwiejności wyborczej wzbudza coraz większe zainteresowanie badaczy.

Celem niniejszego artykułu jest weryfikacja czynników decydujących o specyfice chwiejności wyborczej na poziomie lokalnym. Polityka lokalna kieruje się innymi prawami, odmiennymi kanałami dociera do wyborców, inaczej ich aktywizuje. W większej mierze dostępne są jej mechanizmy bliższe obywatelom, dotykające bezpośrednio ich codziennego życia. Artykuł podejmuje analizę uwarunkowań, które odgrywają istotną rolę w generowaniu modeli zachowań wyborczych na poziomie lokalnym. Przedstawiona refleksja obejmuje czynniki wynikające z drugorzędności wyborów samorządowych, szczególne motywacje wyborcze obywateli, tematy kampanijne oraz specyfikę tworzenia komitetów i generowania kandydatów niezwiązanych z partiami politycznymi. Refleksję poprzedza przedstawienie głównych zagadnień teoretycznych związanych z chwiejnością wyborczą.

\section{CHWIEJNOŚĆ WYBORCZA}

Chwiejność wyborcza jest powszechnym wskaźnikiem stabilności systemu partyjnego i jego otwartości na nowe podmioty polityczne (Bartolini, Mair, 1990; Dassonneville, Hooghe, 2011). Wyjściowym założeniem przyjmowanym w analizach jest dość powszechnie wskazywana zależność, że im bardziej stabilny system partyjny, tym bardziej zdolny do wytwarzania stałych wzorców podziału głosów pomiędzy partie polityczne w czasie (Shair-Rosenfield, 2008, s. 5). Wysoki poziom chwiejności wyborczej odzwierciedla odrzucenie bądź słabą legitymację dla rządu oraz ukazuje, że partie polityczne nie potrafią wytworzyć silnych platform programowych czy ideologicznych, które mogłyby stabilnie spajać z nimi wyborców (Mainwaring, Scully, 1995).

Traktowanie chwiejności wyborczej jako wskaźnika odzwierciedlającego poziom stabilności systemu partyjnego prowadzić jednak może do swoistego błędu poznawczego, w konsekwencji którego dochodzi do generalnego wartościowania chwiejności wyborczej. Fundamentem wskazanego błędu jest dość powszechne przekonanie, że stabilność - w szczególności w odniesieniu do demokracji - jest oceniana pozytywnie, natomiast niestabilność - negatywnie. Stabilność łączona jest z instytucjonalizacją, wypracowaniem trwałych reguł i zasad funkcjonowania politycznego, jak również silnymi relacjami pomiędzy 
wyborcami a podmiotami politycznymi. Niestabilność z kolei z trudnościami we wspólnym działaniu na rzecz rozwoju państwa, brakiem przełożenia działań na ich efekty, konfliktowością i wysokim poziomem zmienności sceny partyjnej. Domniemane związki nie mają jednak przełożenia na rzeczywistą praktykę. W zakresie badań nad systemami partyjnymi chwiejność jest niezbędnym elementem „żywotności” sceny partyjnej. Mimo że nadmierna chwiejność jest oceniana negatywne i destabilizująco dla zarządzania, to jednak demokracja wymaga pewnego poziomu chwiejności (Drummond, 2006, s. 628-647; Granberg, Holmberg, 1990, s. 530-550). Chwiejność może być także traktowana jako czynnik adaptacji systemu partyjnego do zmieniających się warunków zewnętrznych. Zmiana otoczenia może inicjować zmianę politycznej reprezentacji. Zmiana ta może być związana np. z sytuacją ekonomiczną, ale także z procesami zachodzącymi w strukturze społecznej (demografia, zanikanie rolników czy klasy robotniczej itp.).

Wynik poparcia partii politycznej jest podstawową jednostką analizy chwiejności wyborczej. Jest to ważne zarówno z teoretycznego, jak i praktycznego punktu widzenia. Partie polityczne są głównymi reprezentantami obywateli na scenie politycznej. Jedną z fundamentalnych funkcji partii politycznych (obok państwowo-publicznej i organizacyjnej) jest funkcja społeczna (Herbut, 1997, s. 68 i nast.), która w mniejszym lub większym zakresie wiąże partię polityczną ze strukturą społeczną. Uzyskanie mandatu zapewnia odpowiednia liczba głosów zdobytych w elekcji, co wiąże się z opracowaniem i wdrożeniem odpowiedniej strategii wyborczej, ukierunkowanej na pozyskanie niezbędnych głosów. „Strategia ta jest swoistego rodzaju towarem wprowadzonym na rynek wyborczy, ofertą programową przedstawioną masowemu wyborcy, która staje się z reguły punktem odniesienia indywidualnej decyzji wyborczej (...) z reguły opiera się na określonej koncepcji definiującej ideologiczną i programową tożsamość partii” (Herbut, 1997, s. 69). Wynik wyborczy jest zatem konsekwencją interakcji między wyborcami a partią polityczną. Analizy chwiejności wyborczej odzwierciedlają zmiany tych relacji w czasie i na różnych poziomach.

\section{DRUGORZĘDNOŚĆ WYBORÓW I JEJ SPECYFIKA}

Karlheinz Reif i Hermann Schmitt zwracają uwagę na co najmniej dwie płaszczyzny eksploracji wyborczej o różnym charakterze. Pierwszą są wybory krajowe - prezydenckie i parlamentarne - które posiadają wyższy status systemowej 
i społecznej istotności. Drugi obszar ma charakter drugorzędny i składają się na niego wybory samorządowe oraz do Parlamentu Europejskiego. Jest to podział umowny, który może podlegać krytyce, w szczególności w odniesieniu do wyborów samorządowych. Możemy spotkać się z teoriami, które nadają elekcjom lokalnym status swoistej nieistotności (Miller, 1998, s. 9-12). Uwarunkowań tego stanu autorzy upatrują m.in. (1) w wywoływaniu apatii wśród wyborców (spowodowanej np. zbyt dużym nagromadzeniem elekcji w krótkim czasie, które wzajemnie będą osłabiały swoją wagę i jednocześnie mogą generować bierność wyborczą, (2) w zwiększaniu polaryzacji politycznej (np. poprzez podejmowanie tematów kampanijnych oddalonych od głównego nurtu reprezentowanej partii) czy wikłaniem partii w gry polityczne o słabym znaczeniu (np. poprzez skupianie się na działaniach pozornych, negatywnych, osłabiających przeciwnika, a nie realnej aktywności politycznej) (Drachman, R. Langran, 2008, s. 134).

Drugorzędność wyborów nadaje im specyficzny charakter, który będzie utrudniał wykrystalizowanie się stabilnych wzorców zachowań wyborczych (Marsc, 1998, s. 591-607). Robert Wiszniowski przypisuje elekcjom drugiego rzędu trzy fundamentalne cechy. Są to wybory, w których obserwujemy niższy poziom partycypacji politycznej wynikający z mniejszej polityzacji, a tym samym mobilizacji wyborców; (b) traktowanie przez wyborców wyborów drugorzędnych jako sposobu wyrażenia niezadowolenia z rządzących; (c) postrzeganie wyborów jako drugoplanowych daje mniej powodów do głosowania strategicznego - następuje głosowanie zgodnie z naturalnymi preferencjami, czego skutkiem jest większe poparcie dla partii małych. Jak zauważają Reif i Schmitt (1980, s. 3-44), wybory drugiego rzędu pozostają pod wpływem elekcji pierwszego rzędu. Sytuacja na scenie politycznej będzie kontekstem decyzji wyborczych. Przykładowo może stanowić dla części wyborców możliwość, w której będą oni chcieli pokazać niezadowolenie z działań partii na poziomie ogólnonarodowym. Jak podkreślają Reif i Schmitt, w wyborach drugiego rzędu wyborcy zdecydowanie częściej głosują sercem, a nie głową. Będzie to z jednej strony miało związek z odejściem od głosowania strategicznego, z drugiej jednak „serce” to poddaje się różnym emocjom, nastrojom, które generowane na scenie ogólnonarodowej mogą stanowić filtr dla zachowań wyborczych w przestrzeni lokalnej.

Jednoznaczne klasyfikowanie wyborów samorządowych jako drugorzędnych w Polsce komplikują pojawiające się coraz częściej analizy, które ukazują coraz większą ich rangę. Wyniki analiz Waldemara Wojtasika (2010) dowodzą, że koncepcja second order elections, nie daje się w sposób prosty rozszerzyć na rodzime wybory samorządowe. Badania CBOS również zwracają uwagę, że od 
kilku lat pod względem przypisywanego im przez Polaków znaczenia wybory te przewyższają parlamentarne, a nawet prezydenckie (CBOS 124/2014). Mirosława Marody (2010) pisze wręcz: „choć większość ludzi nadal czuje się dumnymi $\mathrm{z}$ bycia Polakami, to państwo przestaje być dla nich punktem odniesienia, a decyzje władz czynnikiem sprawczym dla ich zachowań. Oni gdzie indziej lokują swoje lojalności, sympatie, zainteresowania. Ważne jest to, co dzieje się w ich najbliższym otoczeniu (...). Niezbyt ich interesuje, kto będzie zasiadał w Sejmie, bo dla ich życia to nie jest istotne. Nie interesuje ich, czy władza cieszy się szacunkiem, czy, choć oczywiście woleliby, żeby władza była sprawna”. Obserwacja ta wymaga jednak dalszych weryfikacji, które ukażą konsekwencje takiego stanu rzeczy dla tworzenia się stabilnych wzorców zachowań wyborczych.

\section{MOTYWACJE WYBORCZE}

Jak zaznaczono, wybory samorządowe charakteryzują się słabszym mechanizmem głosowania strategicznego, który ma istotniejsze znaczenie w wyborach szczebla ogólnokrajowego. Tym samym inne będą uwarunkowania alokacji głosów wyborczych. W elekcjach lokalnych większe znaczenie ma akcentowanie przywiązania do regionu niż partyjne odniesienia. W miejscowościach, gdzie zakorzenione są silne tożsamości lokalne, instytucjonalizowane często w postaci ruchów i stowarzyszeń, integrujących społeczność nie tylko w trakcie wyborów, ale permanentnie, chwiejność wyborcza będzie niższa. Tożsamość lokalna jest szczególnym przypadkiem tożsamości społecznej, opiera się na tradycji lokalnej, odnoszonej do wyraźnie zdefiniowanego i delimitowanego terytorium, regionu (miejsca), jego specyficznych cech społecznych, kulturowych (symbolicznych), gospodarczych czy nawet topograficznych, wyróżniających go spośród innych regionów (miejsc) (Szczepański, Sliz, 2010, s. 15-19). Ukształtowana najczęściej prowadzi do zachowań prospołecznych, ukierunkowanych na podtrzymanie tradycji, więzi z mieszkańcami danego miejsca. Wiąże się silnie z wartościami pielęgnowanymi przez wspólnotę, stylem życia, regularnymi aktywnościami. Wszystko to będzie wzmacniało więzi z podmiotem, który będzie pielęgnował przywiązanie do miejsca i tożsamość regionalną mieszkańców. Będzie dawał poczucie wspólnotowości i reprezentacji społecznej. Tym samym można przypuszczać, że będzie generował stabilne zachowania wyborcze.

Po drugie w miejscach, które nie ukształtowały silnych tożsamości lokalnych, wybory stają się otwarte na kandydatów, którzy zdobywają mniejszą 
bądź większą popularność z uwagi na doraźne osiągnięcia bądź aspiracje do władzy oparte na pełnionych funkcjach czy stanowiskach. Poparcie społeczne będzie bardziej incydentalne, związane z bieżącymi wydarzeniami, kampanią wyborczą, aspiracjami kandydatów. Zachowania wyborcze w mniejszym stopniu będą generowane przez względnie stabilne wartości, potrzeby, co wpłynie bez wątpienia na chwiejność zachowań zarówno na poziomie aktywności/bierności wyborczej, jak i samej preferencji wyborczej.

Inną kwestią, która będzie istotnie wpływała na chwiejność wyborczą na poziomie lokalnym, jest bliskość z kandydatami, co stanowi szczególną motywację w elekcji. Aktywizacja wyborcza lub alokacja głosu wyborczego może być generowana przez efekt częstości kontaktów. Polega on na tym, że im częściej kontaktujemy się z daną osobą, im częściej się widzimy, tym większe prawdopodobieństwo uaktywnienia sympatii wobec niego. Efekt ten zatem będzie miał większe znaczenie w przypadku kandydatów z sąsiedztwa, wspólnoty lokalnej czy środowiska zawodowego. Tym samym, podobnie jak szczególne problemy, może mieć charakter doraźny, może też mieć charakter wypierający merytoryczny dyskurs na rzecz psychologicznej bliskości.

Motywacje wyborcze obywateli będą weryfikowane przez czynniki systemowe, takie chociażby jak skomplikowana ordynacja wyborcza, różna w wyborach do poszczególnych organów samorządowych. W miastach na prawach powiatu, powiatach oraz sejmikach wojewódzkich obowiązuje ordynacja proporcjonalna. We wszystkich pozostałych - większościowa. Sytuacja ta wymaga od wyborcy wiedzy o sposobie głosowania i kompetencji umożliwiających ocenę skutków własnych zachowań wyborczych. Co więcej, może ona wiązać się z faktem stopniowania istotności wyborów samorządowych w zależności od organów. Może być również źródłem błędów wyborczych, związanych z niepokrywaniem się intencji i motywacji wyborców z wynikiem głosowania. Widomym efektem tego będzie m.in. stosunkowo wysoki odsetek głosów nieważnych, diagnozowany w wyborach do sejmików.

\section{BLISKOŚĆ TEMATÓW KAMPANIJNYCH}

Minimalizowanie mechanizmu głosowania strategicznego generuje uaktywnienie w wyborach lokalnych przestrzeni dla specyficznych tematów kampanijnych. Polityka lokalna to ważna sfera, związana z decyzjami bezpośrednio wpływającymi na funkcjonowanie danej osoby w miejscu zamieszkania. Daje 
to większe pole dla uaktywnienia konwersji w wyborach lokalnych. „Aby interes jakiejś społeczności pobudził aktywność polityczną jednostki, musi stać się także jej subiektywnym interesem. Gdy taki proces przemiany interesu wspólnego na subiektywny nastąpi, osoba zaczyna przywiązywać większą wagę do zachowań politycznych i realizacji celów politycznych związanych z subiektywnym i wspólnym interesem" (Skarżyńska, 2002, s. 47). Krystyna Skarżyńska, analizując badania innych autorów, zwraca uwagę, że wspólny interes jakiejś zbiorowości ma szansę przekształcić się w interes subiektywny, gdy problem dotyczy małego obszaru (np. najbliższego sąsiedztwa), ponadto musi być rozwiązywany w określonym czasie oraz być konkretnie zdefiniowany (Skarżyńska, 2002, s. 42). Mechanizm ten z pewnością łatwiejszy jest do wykorzystania przez lokalne władze, których obszar aktywności przekłada się na najbliższe interesy jednostek - ich ulicę, plac zabaw, szkołę, park.

Tematy na poziomie ogólnopaństwowym mają w większej mierze charakter ogólny, oddalony od wyborców, a niejednokrotnie na efekty spełnienia wyborczych obietnic trzeba czekać latami. Problemy poruszane w trakcie kampanii lokalnej są istotnie częściej konkretniejsze, bliższe obywatelom. Co więcej, bliskość ta sprawia, że wyborcy mają również większą wiedzę na dany temat i potrafią ją aplikować w proces podejmowania decyzji. Jeśli identyfikują się $\mathrm{z}$ danym problemem, angażują się $\mathrm{w}$ kampanię poprzez dyskusje $\mathrm{z}$ innymi mieszkańcami, śledzenie wydarzeń wyborczych, spotkania $z$ kandydatami. W myśl reguły konsekwencji (Cialdini, 2013) to zaangażowanie częściej będzie generowało aktywne uczestnictwo w elekcji.

Powyższe będzie istotnie oddziaływało na chwiejność wyborczą. Specyfika tematów poruszanych w wyborach lokalnych sprawia, że są one doraźne, zmieniają się często $\mathrm{z}$ kampanii na kampanię. O ile nie dotyczą kwestii tożsamościowych, co zostało opisane wyżej, mogą generować różne zainteresowanie obywateli i jednocześnie ich różną aktywność wyborczą zarówno na poziomie aktywność/bierność wyborcza, jak też alokacja głosu wyborczego. Podczas jednej elekcji będą dotyczyły ośrodka zdrowia, który jest przedmiotem zainteresowania wyborcy, podczas gdy w kolejnej ten sam podmiot będzie ogniskował swoją kampanię na modernizacji szkół, co z uwagi przykładowo na wiek czy nieposiadanie dzieci przez wyborcę, nie będzie go angażowało. Chwiejność będzie zatem nie tylko generowana przez alokację głosu wyborczego z uwagi na odmienne tematy poruszane przez różne podmioty, ale również poprzez generalne angażowanie wyborcy w kampanię.

Bliskość problemów pozwala również w większym stopniu na uaktywnienie mechanizmu rozliczalności, co będzie istotnie wpływało na chwiejność wybor- 
czą. Praktycyzm i obywatelska bliskość tematów elekcyjnych będą wiązały się z wyrazistym mechanizmem głosowania poprzez karanie i nagradzania podmiotów, co jest integralnym elementem głosowania retrospektywnego. Poprzez wyraźne sformułowanie konkretnych obietnic w kampanii istotnie łatwiejsze jest dokonanie oceny efektywności działań kandydata w procesie ich realizacji. Zasadność głosowania retrospektywnego obarczana jest powszechnie podstawowym zarzutem, który wiąże się z koniecznością posiadania określonych kompetencji co do oceny sytuacji na poziomie mikrospołecznym (własnej) oraz makrospołecznym (ogólnopaństwowej gospodarki). Założenia teorii wymagają od obywateli umiejętności wstecznej oceny efektów działań podjętych przez rządzących i podjęcia na podstawie tej refleksji decyzji, co do udzielanego im poparcia (Turska-Kawa, 2015, s. 238) Wydaje się, że na poziomie lokalnym i regionalnym proces ten jest istotnie łatwiejszy dla wyborców. Tematy są im bliższe, konkretne, częściej aktywne w przestrzeni publicznej, co będzie generowało dyskusje nad procesem realizacji obietnic wyborczych.

\section{DEPOLITYZACJA KANDYDATÓW}

W elekcji lokalnej dość często spotykamy się ze zjawiskiem, w którym przedstawiciele partii politycznych startują jako niezależni bądź jako reprezentanci lokalnych czy regionalnych podmiotów. W istocie - z uwagi na wspomniane wyżej argumenty, takie jak chociażby mniejsza polityzacja wyborów lokalnych, minimalizacja głosowania strategicznego czy specyficzne motywacje tożsamościowe - zwiększa to ich szanse wyborcze. Wskazane zjawisko będzie sprawiało, że kandydaci będą odchodzili od głównego nurtu ideologicznego partii politycznej, podejmując dyskusję nad problemami bliskimi mieszkańcom. Odejście od ideologicznych kwestii na rzecz bardziej pragmatycznych, konkretnych dla danej społeczności lokalnej, stanowi odpowiedź na odmienne uwarunkowania zachowań wyborczych na poziomie lokalnym.

Powyższe jest wynikiem z jednej strony odejścia od głosowania strategicznego, ale z drugiej wyrazem słabego zaufania do partii politycznych, które od wielu lat obserwujemy w Polsce. Przed ostatnimi wyborami samorządowymi prawie dwie trzecie uprawnionych do głosowania zadeklarowało, że w wyborach do rady swojego miasta/gminy woleliby zagłosować na kandydatów niezwiązanych z żadną partią. Rekomendacja partyjna w przedwyborczych deklaracjach okazała się istotna wyłącznie dla nieco ponad jednej szóstej ankietowanych 
(CBOS, 124/2014). Tendencja deklaratywna ma charakter depolityzujący wybory samorządowe, co prezentuje tabela 1 . Widać w niej wyraźnie, że z każdą kolejną elekcją wzrasta poparcie dla kandydatów niezwiązanych z podmiotami politycznymi.

Tabela 1. Deklaracje przedwyborcze obywateli w odniesieniu do preferowanych kandydatów do rady miasta/gminy

\begin{tabular}{|l|c|c|c|}
\hline \multicolumn{1}{|c|}{$\begin{array}{c}\text { Czy w wyborach do Rady Pana(i) miasta/gminy } \\
\text { wolał(a)by Pan(i) głosować }\end{array}$} & $\begin{array}{c}2006 \\
(\mathbf{w} \%)\end{array}$ & $\begin{array}{c}2010 \\
(\mathbf{w} \%)\end{array}$ & $\begin{array}{c}2014 \\
(\mathbf{w} \%)\end{array}$ \\
\hline Na kandydatów jakiejś partii, ugrupowania politycznego & 21 & 22 & 17 \\
\hline $\begin{array}{l}\text { Na kandydatów niezwiązanych z żadną partią, ugrupowaniem } \\
\text { politycznym }\end{array}$ & 50 & 52 & 65 \\
\hline Trudno powiedzieć & 29 & 26 & 18 \\
\hline
\end{tabular}

Źródło: CBOS.

Jeszcze wyraźniejsze deklaracje w zarysowanym kierunku widać w perspektywie elekcji wójtów, burmistrzów i prezydentów miast. Przed ostatnimi wyborami samorządowymi preferencje dla kandydatów niezależnych od partii politycznych deklarowało dwie trzecie uprawnionych do głosowania, co stanowiło wzrost o blisko 20 punktów procentowych w porównaniu z rokiem 2010.

Tabela 2. Deklaracje przedwyborcze obywateli w odniesieniu do preferowanych kandydatów na wójtów, burmistrzów czy prezydentów miast

\begin{tabular}{|c|c|c|c|}
\hline $\begin{array}{l}\text { Czy w wyborach na wójtów/burmistrzów/prezydentów miast } \\
\text { wolał(a)by Pan(i) głosować }\end{array}$ & $\begin{array}{l}2006 \\
(w \%)\end{array}$ & $\begin{array}{l}2010 \\
(w \%)\end{array}$ & $\begin{array}{r}2014 \\
(w \%)\end{array}$ \\
\hline $\begin{array}{l}\text { Na kandydata popieranego przez jakąś partię, ugrupowanie } \\
\text { polityczne }\end{array}$ & 22 & 24 & 17 \\
\hline $\begin{array}{l}\text { Na kandydata niezwiązanego } z \dot{z} a d n a \text { partia, ugrupowaniem } \\
\text { politycznym }\end{array}$ & 52 & 48 & 67 \\
\hline Trudno powiedzieć & 26 & 28 & 16 \\
\hline
\end{tabular}

Źródło: CBOS.

Wraz ze wzrostem jednostki samorządowej i przechodzeniem z poziomu lokalnego na regionalny preferencja do głosowania na osobę zostaje osłabiona, a zastępuje ją mechanizm pozycjonowania ideologicznego i popierania kandydata $\mathrm{z}$ formacji pierwszego wyboru. W Polsce obrazuje to różnica między 
wynikami wyborów w gminach (gdzie w znacznej mierze zwyciężają kandydaci niezależni) a sejmikami województw (gdzie szala zwycięstwa przechyla się w kierunku przedstawicieli partii politycznych) (Wojtasik, 2013, s. 212-213). Dominacja kandydatów niezależnych będzie sprawiała, że wynik wyborów będzie odzwierciedlał rzeczywiste zainteresowanie wyborców programami wyborczymi oraz popularność poszczególnych kandydatów w środowiskach lokalnych.

\section{ZAKOŃCZENIE}

Wybory lokalne w Polsce stanowią szczególne pole ekspresji zachowań wyborczych, którym trudno nadać stabilne ramy. Systemowa i społeczna specyfika tychże elekcji generuje szereg czynników, które oddziałują na chwiejność wyborczą, a ich analiza była celem przedstawianej refleksji. Zachowania wyborcze będą stabilniejsze tam, gdzie silnie zakorzenione są podmioty odwołujące się w wyborach do tożsamości lokalnych mieszkańców. Stabilność będzie zasadzała się na związkach tej relacji z wartościami, stylem życia czy poczuciem przynależności do wspólnoty. Istotnie częściej jednak będziemy mieli do czynienia z sytuacją zwiększającą chwiejność wyborczą. Za proces ten odpowiedzialne będą m.in. cechy wyborów wynikające $\mathrm{z}$ ich społecznej rangi, doraźne motywacje wyborcze w miejscach o słabo wykrystalizowanych tożsamościach regionalnych, relacje z kandydatem czy bliższe i konkretniejsze tematy kampanijne.

W przypadku elekcji lokalnych warto spojrzeć na chwiejność wyborczą z nieco innej perspektywy. Z uwagi na doraźne, omówione wyżej grupy czynników leżących u podstaw niestabilności, można dostrzec istotnie pozytywny aspekt pozornej niestabilności. Mianowicie chwiejność ta może być wskaźnikiem zaangażowania mieszkańców w proces budowania i doskonalenia ich najbliższego otoczenia. Idąc dalej, polityka lokalna będzie wówczas fundamentem tworzenia i aktywizowania dobrych wzorców obywatelskich. Kampania wyborcza na poziomie lokalnym powinna aktywizować, rozbudzać poczucie odpowiedzialności za własne otoczenie. Odwołując się do potrzeb wspólnotowych i poczucia przynależności mieszkańców, powinna umacniać relacje nie tylko między obywatelami, ale również między nimi i regionem. Pozytywne bliskie i konkretne cele angażujące w trakcie kampanii wyborczych, które jednostka potrafi przełożyć na jakość życia swojego i najbliższych, mogą istotnie uczyć współdziałania, budować zaufanie interpersonalne. Jest to ważna płaszczyzna 
kształtowania kapitału społecznego. Tym bardziej istotna, że od ponad 20 lat, odkąd w Polsce prowadzi się nad nim badania, nie posunęliśmy się ani o krok do przodu.

Co więcej, powyższa obserwacja będzie pozytywnie oddziaływała na obywatelskie kompetencje polityczne obywateli, które obejmują zarówno wiedzę o polityce (którą bardzo często uzależnia się od stopnia zainteresowania polityką), wartości, zaufanie społeczne, jak i wreszcie, pod wpływem wyżej wymienionych czynników, działanie. Umożliwiają zatem świadomą partycypację polityczną, przez co stanowią odzwierciedlenie wykształconych w jednostce kompetencji społecznych i obywatelskich. Pozwalają także jednostce na formowanie i wykorzystywanie własnej podmiotowości w kształtowaniu dobra wspólnego. Wymiar lokalny polityki, dając większe możliwości zaangażowania, może istotnie wpływać na świadomie kształtującą się podmiotowość polityczną jednostki. Chwiejność wówczas może być konsekwencją nie tyle słabej identyfikacji politycznej jednostki, ale jej świadomej aktywności.

Oczywiście można powyższe kontrować tezami o rozwoju technik i narzędzi marketingu politycznego, których celem jest mobilizowanie mieszkańców do lokowania głosów wyborczych w określonym kierunku. Wydaje się jednak, że na poziomie lokalnym ma to mniejsze znaczenie. Specyfika poruszanych tematów kampanijnych, ich bliskość, konkretyzm w porównaniu ze znaczną częścią problemów podejmowanych na poziomie wyborów ogólnopaństwowych, generują większe możliwości rozliczalności podmiotów politycznych na poziomie lokalnym. Istotnie łatwiej karać i nagradzać podmioty polityczne za ich aktywność w najbliższym otoczeniu, jeśli zostały poczynione konkretne obietnice. Mimo generalnych trudności z oceną retrospektywną, można sądzić, że na poziomie lokalnym łatwiej być „racjonalnym wyborcą” niż na poziomie ogólnopaństwowym, gdzie wiele kwestii jest poza zasięgiem wiedzy i kompetencji obywateli. Rozliczalność ta będzie również istotnym mechanizmem angażującym i wspierającym zarysowane wyżej procesy.

\section{BibLIOGRAFIA:}

Bartolini S., Mair P. (1990). Identity, competition and electoral availability: The stabilization of European electorates, 1885-1985. Cambridge: Cambridge University Press.

CBOS, 124/2014. Wybory samorzadowe, komunikat z badań. Warszawa.

Chaffee S., Sun Y.Ch. (1980). Time of Decision and Media Use During the Ford-Carter Campaign. Public Opinion Quarterly, 44(1), 53-69. 
Cialdini R. (2013). Wywieranie wpływu na ludzi. Teoria i praktyka. Gdańsk: Gdańskie Wydawnictwo Psychologiczne.

Converse, P.E. (1962). Information Flow and the Stability of Partisan Attitudes. Public Opinion Quarterly, 26(4), 578-599;

Dalton, R.J., Beck, P.A., Flanagan Scott C. (1984). Electoral change in advanced industrial democracies. W: R.J. Dalton, P.A. Beck, S.C. Flanagan (red.), Electoral change in advanced industrial democracies: realignment or dealignment? (s. 3-22). Princetown: Princetown University Press;

Dalton, R.J., Wattenberg, M.P. (1993). The Not So Simple Act of Voting. W: A. Finifter (red.), The State of the Discipline II (s. 193-218). Washington, DC: The American Political Science Association.

Dassonneville R., Hooghe, M. (2011). Mapping Electoral Volatility in Europe, An analysis of trends in electoral volatility in European democracies since 1945. Paper presented at the $1^{\text {st }}$ European Conference on Comparative Electoral Research.

Drachman, E.R., Langran, R. (2008). You Decide: Controversial Cases in American Politics. Lanham: Rowman \& Littlefield.

Drummond, A.J. (2006). Electoral Volatility and Party Decline in Western Democracies: 1970-1995. Political Studies, 54(3), 628-647.

Franklin, M., Mackie, T., Valen H. (1992). Electoral Change. Cambridge: Cambridge University Press.

Granberg, D., Holmberg, S. (1990). The Berelson Paradox reconsidered intension-behavior changers in U.S. and Swedish Election Campaigns. Public Opinion Quarterly, 54(4), 530-550.

Hayes, B.C., McAllister, I. (1996). Marketing Politics to Voters: Late Deciders in the 1992 British Election. European Journal of Social Psychology, 33, 223-231.

Herbut R. (1997). Partie polityczne. W: A. Antoszewski, R. Herbut (red.), Demokracje zachodnioeuropejskie. Analiza porównawcza (s. 65-101). Wrocław: Wydawnictwo Uniwersytetu Wrocławskiego.

Lud urabia sobie państwo, wywiad z prof. Mirosławą Marody, http://wyborcza. pl/1,76842,8455054,Lud_urabia_sobie_panstwo.html?as=2startsz=x\#ixzz1AFJWY6RH"

Mainwaring, S., Scully, T. (1995). Building Democratic Institutions: Party Systems in Latin America. Palo Alto, Calif.: Stanford University Press.

Mair, P. (2005). Democracy Beyond Parties. Irvine (UC): Center for the Study of Democracy.

Marsc, M. (1998). Testing the Second-Order Election Model after Four European Elections, British Journal of Political Science, 28(04), 591-607.

Miller, W.L. (1998). Irrelevant elections? The Quality of Local Democracy in Britain, Oxford: Clarendon Press.

Reif K., Schmitt, H. (1980). Nine Second Order National Elections: A Conceptual Framework for the Analysis of European Election Results. European Journal of Political Research, 8 (1980), 3-44. 
Shair-Rosenfield S. (2008). Assessing the Causes and Effects of Electoral Volatility: Party System Fragmentation, Time and Executive Turnover. Chapel Hill: ProQuest.

Skarżyńska, K. (2002). Podstawy psychologii politycznej. Poznań: Zysk i S-ka.

Szczepański, M., Sliz, A. (2010). Dylematy regionalnej tożsamości. Przypadek Górnego Śląska. Śląsk, nr 10,

Turska-Kawa, A. (2015). Determinanty chwiejności wyborczej. Katowice: Wydawnictwo Uniwersytetu Śląskiego.

Wojtasik, W. (2010). Drugorzędność wyborów samorządowych w teorii i badaniach empirycznych. W: M. Barański, A. Czyż, S. Kubas (red.), Rola samorządu terytorialnego w modernizacji Polski (253-269). Katowice: Wydawnictwo Uniwersytetu Śląskiego.

Wojtasik, W. (2013). Istotność wyborów i jej czynniki w świadomości społecznej. Political Preferences, 2, 205-226.

Zaller, J. (2003). A New Standard of News Quality: Burglar Alarms for the Monitorial Citizen. Political Communication, 20(2), 109-130.

Zukin, C. (1977). A Reconsideration of the Effects of Information on Partisan Stability. Public Opinion Quarterly, 41 (summer), 244-254. 